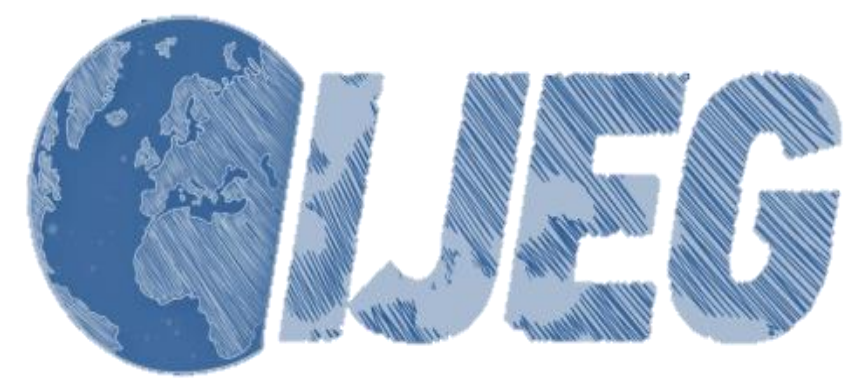

International Journal of Engineering and Geosciences (IJEG),

Vol; 5, Issue; 2, pp. 060-065, June, 2020, ISSN 2548-0960, Turkey, DOI: $10.26833 /$ ijeg.573503

\title{
COMPARATIVE ANALYSIS OF THE PYSEBAL MODEL AND LYSIMETER FOR ESTIMATING ACTUAL EVAPOTRANSPIRATION OF SOYBEAN CROP IN ADANA, TURKEY
}

\author{
Alidou Sawadogo ${ }^{1 *}$, Hessels Tim ${ }^{2}$, Kemal Sulhi Gündoğdu ${ }^{1}$, Ali Osman Demir ${ }^{1}$, Mustafa Ünlü ${ }^{3}$, Sander Jaap. Zwart ${ }^{4}$ \\ ${ }^{1}$ Uludag University, Faculty of Agriculture, Biosystems Engineering Department, Bursa-Turkey. \\ (sawadogoalidou@yahoo.fr; kemalg@uludag.edu.tr; aodemir@uludag.edu.tr); ORCID 0000-0002-7437-8415, ORCID \\ 0000-0002-5591-4788, ORCID 0000-0003-3409-6680 \\ ${ }^{2}$ UNESCO-IHE Institute for Water Education, Delft, The Netherland. (timhessels@ hotmail.com); \\ ORCID 0000-0002-7264-7220 \\ ${ }^{3}$ University of Çukurova, Faculty of Agriculture, Department of Agricultural Structures and Irrigation, Adana - Turkey. \\ (munlu@cu.edu.tr); ORCID 0000-0002-1889-516X \\ ${ }^{4}$ University of Twente, Faculty of Geo-Information Science and Earth Observation, Department of Natural Resources.
} (s.zwart@ cgiar.org); ORCID 0000-0002-5091-1801

*Corresponding Author, Received: 02/06/2019, Accepted: 18/09/2019

\begin{abstract}
Accurate estimation of evapotranspiration (ET) is an important factor in water management, especially in irrigated agriculture. Accurate irrigation scheduling requires accurate estimation of ET. The objective of this study was to estimate the actual evapotranspiration (ETa) by the pySEBAL model and to compare it with the actual evapotranspiration measured by the lysimeter method of soybean crop in Adana, Turkey. Five Landsat 5 Thematic Mapper (TM) images and weather data were used for this study to estimate actual evapotranspiration by the pySEBAL model. The results showed a good relationship between $\mathrm{ET}_{\mathrm{a}}$ estimated by the pySEBAL model and $\mathrm{ET}_{\mathrm{a}}$ measured by the lysimeter method, with an $\mathrm{R}^{2}$ of 0.73 , an

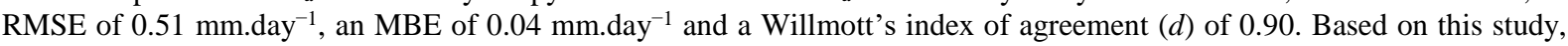
there is a good relationship between the actual evapotranspiration estimated by the pySEBAL model and the actual evapotranspiration measured by the lysimeter method. Consequently, $\mathrm{ET}_{\mathrm{a}}$ of soybean crop can be estimated with high accuracy by the pySEBAL model in Adana, Turkey.
\end{abstract}

Keywords: Actual Evapotranspiration, Lysimeter, PySEBAL Model, Remote Sensing. 


\section{INTRODUCTION}

Freshwater resources are becoming increasingly scarce in many parts of the world (Anonymous, 2007) and agriculture is the largest water user worldwide (FAO, 2011). Water use in agriculture is one of the main causes of the water scarcity, and according to the FAO (2009), the world's population is predicted to increase to 9.1 billion people by 2050 . Face to this reality, there is a need to increase agricultural water productivity in a sustainability way to meet rising demands for water and food. Water productivity can be improved by increasing yield using less water. This could be done by proper irrigation management practices. In this process, more water could be save to meet the rising demand for water. To improve water productivity by proper irrigation management, a precise knowledge of evapotranspiration is required. ET can be estimated by many methods such as direct measurements using the lysimeters (Allen et al., 1998) and indirect measurements using remote sensing-based methods (Bastiaanssen, 1995).

The remote sensing model, such as the Surface Energy Balance Algorithm for Land (SEBAL) model developed by Bastiaanssen et al. (1998), is used to estimate the $\mathrm{ET}_{\mathrm{a}}$ (Bastiaanssen et al., 2005). Other energy balance models such as the Surface Energy Balance System (SEBS) developped by Su (2002), the Simplified Surface Energy Balance Index (S-SEBI) developed by Roerink et al. (2000) and most recently, the Mapping Evapotranspiration at high Resolution with Internalized Calibration (METRIC) algorithm developed Allen et al. (2007) to estimate the crop water consumption. SEBAL has been validated in many countries under a wide variety of conditions (Bastiaanssen et al., 2005) and has been identified as the most promising approach currently available to estimate evapotranspiration. The Python module for Surface Energy Balance Algorithm for Land (pySEBAL) model was developed by the IHE-Delft Institute for Water Education. Lysimeters, both weighing and drainage types, are considered as basic method to calibrate evapotranspiration models (Mata et al., 1999; Centinari et al., 2009). Weighing lysimeters are considered as standard for ET measurements. However, due to their high prices, these units are few in number at any given location.

To estimate crop water use for irrigation management, remote sensing-based methods may be more appropriate than lysimeters. One of the main advantages of remote sensing-based methods is their ability to provide the spatial variability of the ET under a different range of scales. There is a general consensus that the SEBAL model provide reliable measure of $\mathrm{ET}_{\mathrm{a}}$. However, the model need to be validated for a given area. The accuracy of the evapotranspiration determined from SEBAL model can be assessed from lysimeters data. In this study, the pySEBAL model was applied to estimate actual evapotranspiration of soybean crop in Adana, Turkey. The estimated $\mathrm{ET}_{\mathrm{a}}$ from the pySEBAL model was compared with the ETa measured by the lysimeter method and the accuracy of the pySEBAL model to estimate $\mathrm{ET}_{\mathrm{a}}$ of soybean crop in Adana, Turkey was discussed.

\section{MATERIALS AND METHODS}

\subsection{Lysimeter Data Collection}

In this study, secondary data of actual evapotranspiration measured by lysimeter is used (Table.1). Actual evapotranspiration was directly measured by a weighing lysimeter in the center of 0.12 ha field at Research Fields of the Agricultural Structures and Irrigation Department, Faculty of Agriculture, University of the Cukurova $\left(37^{\circ} 1^{\prime} \mathrm{N}, 35^{\circ} 21^{\prime} \mathrm{E}\right.$, and $20 \mathrm{~m}$ above sea level) Adana, Turkey. Turkey is between the $36^{\circ}$ and $42^{\circ}$ north latitudes and $26^{\circ}$ and $45^{\circ}$ south meridians (Iscan and Ilgaz, 2017; Ernst et al 2019). Lysimeter was used to measure well-watered soybean (Glycine $\max$ L.) evapotranspiration growing in 2009 season. Arioglu soybean cultivar was used in this study. Soybean crop have been sown on 175 Day of year (DOY) and inter and intra row distances of $0.70 \mathrm{~m}$ and $0.10 \mathrm{~m}$, respectively, were applied. Irrigation was applied using a drip irrigation system (Table.1) and crop growth inside and outside of the lysimeter was homogenous. The fertilization doses of 36 kg.ha ${ }^{-1}$ pure nitrogen and 92 kg.ha $^{-1}$ phosphor, $\mathrm{P}_{2} \mathrm{O}_{5}$, recommended in the region for soybean were applied (Uncu and Arioglu, 2005). The soil texture in the experiment plot is heavy clay, as averagely, with $15.75 \%$ of sand, $19.58 \%$ of silt and $64.62 \%$ of clay, $\mathrm{pH}$ is slightly basic, and it is poor in organic matter. The climate of study area is typical Mediterranean climate, with cool rainy winters, and hot dry summers. Temperature varies from $9.9^{\circ} \mathrm{C}$ in January to 28.1 in August.

Table.1. Irrigation intervals (day of year), depth of irrigation water $(\mathrm{mm})$ and $\mathrm{ET}_{\mathrm{a}}(\mathrm{mm})$

\begin{tabular}{lcc}
\hline Day of Year & Irrigation Water $(\mathrm{mm})$ & lysimeter $\mathrm{ET}_{\mathrm{a}}(\mathrm{mm})$ \\
\hline 177 & 64.0 & 2.7 \\
197 & $\mathrm{na}^{1}$ & 2.9 \\
210 & 43.4 & 3.7 \\
213 & $\mathrm{na}$ & 2.5 \\
223 & 32.3 & 5.0 \\
229 & na & 4.1 \\
231 & 23.6 & 3.8 \\
239 & 24.0 & 4.4 \\
245 & na & 3.5 \\
247 & 26.4 & 4.6 \\
253 & 16.0 & 3.3 \\
261 & 16.5 & 3.8 \\
277 & na & 1.1 \\
\hline
\end{tabular}

${ }^{1}$ na: not applicable

\subsection{Meteorological Data}

Hourly air temperature, wind speed, relative humidity, and solar radiation, were used in the pySEBAL model (Table 2). Weather data were obtained from the Adana meteorology station and from http://www.soda-pro.com for solar radiation. 
Table.2. Meteorological data

\begin{tabular}{ccccc}
$\begin{array}{c}\text { Table.2. Meteorological data } \\
\begin{array}{c}\text { Day of } \\
\text { Year }\end{array}\end{array}$ & $\begin{array}{c}\text { Wind speed } \\
\left({\left.\mathrm{m} . \mathrm{s}^{-1}\right)}^{2}\right.\end{array}$ & Air temperature $\left({ }^{\circ} \mathrm{C}\right)$ & $\begin{array}{c}\text { Relative } \\
\text { humidity }(\%)\end{array}$ & $\begin{array}{c}\text { Solar radiation } \\
\left(\text { W. } \mathrm{m}^{-2}\right)\end{array}$ \\
\hline 197 & 1.1 & 27.5 & 77.7 & 238 \\
213 & 1.2 & 29.2 & 76.3 & 278 \\
229 & 1.2 & 29.0 & 83.3 & 298 \\
245 & 1.2 & 28.9 & 78.7 & 221 \\
277 & 1.3 & 23.3 & 60.8 & 200 \\
\hline
\end{tabular}

Table.3. Landsat scenes information

\begin{tabular}{lllll}
\hline $\begin{array}{l}\text { Number } \\
\text { Year }\end{array}$ & $\begin{array}{c}\text { Day of } \\
\text { Landsat Scene }\end{array}$ & Acquisition day & $\begin{array}{l}\text { Overpass } \\
\text { Time(AM) }\end{array}$ \\
\hline 1 & 197 & LT51750342009197MOR00 & $2009-07-16$ & 10:04:32 AM \\
2 & 213 & LT51750342009213MOR00 & $2009-08-01$ & $10: 04: 47$ AM \\
3 & 229 & LT51750342009229MOR00 & $2009-08-17$ & $10: 05: 01$ AM \\
4 & 245 & LT51750342009245MOR00 & $2009-09-02$ & $10: 05: 16$ AM \\
5 & 277 & LT51750342009277MOR00 & $2009-10-04$ & $10: 05: 40$ AM \\
\hline
\end{tabular}

\subsection{Landsat Images}

Due to the lack of Landsat free cloud images in the period of interest, five Landsat 5 TM clear-sky images were used in this study. Landsat images were downloaded from the Earth Explorer (https://earthexplorer.usgs.gov/) website. Table 3 shows the scene information used in this study.

\subsection{Surface Energy Balance Algorithm for Land (SEBAL)}

The SEBAL model is based on modelling the surface energy balance using remote sensing data. The pySEBAL model was developed by IHE-Delft Institute for Water Education in Python programming language (https://pypi.org/project/SEBAL/). A brief summary of the main algorithms of the pySEBAL model is given below. The model calculates the latent heat flux $\left(\lambda \mathrm{E}, \mathrm{W} \cdot \mathrm{m}^{-2}\right)$ as the residual of surface energy equation:

$\lambda E=R_{n}-G-H$

where $R_{n}$ is the net radiation (W.m- $\left.\mathrm{m}^{-2}\right), \mathrm{G}$ is the soil heat flux $\left(\mathrm{W} \cdot \mathrm{m}^{-2}\right)$ and $\mathrm{H}$ is the sensible heat flux $\left(\mathrm{Wm}^{-2}\right)$.

Net radiation $\left(\mathbf{R}_{\mathbf{n}}\right): R_{n}$ is computed using the following equation:

$\mathrm{R}_{\mathrm{n}}=(1-\alpha) \mathrm{Rs} \downarrow+\mathrm{RL} \downarrow-\mathrm{RL} \uparrow-\left(1-\varepsilon_{0}\right) \mathrm{RL} \downarrow$

where $\alpha$ is the surface albedo, $R s \downarrow$ is the incoming shortwave radiation $\left(\mathrm{W} . \mathrm{m}^{-2}\right), R L \downarrow$ is the incoming longwave radiation $\left(\mathrm{W} . \mathrm{m}^{-2}\right), R L \uparrow$ is outgoing longwave radiation $\left(\mathrm{W} . \mathrm{m}^{-2}\right)$, and $\varepsilon_{0}$ is surface emissivity.

Soil heat flux (G): The following equation is used to calculate $\mathrm{G}$.

$\mathrm{G}=\mathrm{R}_{\mathrm{n}}\left(T_{s}(0.0038+0.0074 \alpha)\left(1-0.978 \times \mathrm{NDVI}^{4}\right)\right)$ where $T_{s}$ is the surface temperature $(K)$ and NDVI is the normalized difference vegetation index.

Sensible heat flux $(\mathbf{H}): \mathrm{H}$ is estimated using the heat transfer equation:

$H=\frac{\rho \times c \rho \times d T}{r a h}$

where $\rho$ is the air density $\left(\mathrm{kg} \cdot \mathrm{m}^{-3}\right) c \rho$ is the specific heat of air at constant pressure $\left(\mathrm{J} \cdot \mathrm{kg}^{-1} \cdot \mathrm{K}^{-1}\right), \mathrm{d} T$ is the vertical near surface temperature difference $(\mathrm{K})$ and $r a h$ is the aerodynamic resistance to heat transport $\left(\mathrm{s} \cdot \mathrm{m}^{-1}\right)$. $\mathrm{H}$ is calculated in an iterative way due to the relationship between the aerodynamic resistance and sensible heat flux. Within the first iteration, a neutral air condition without convection is assumed. This first iteration will result in a sensible heat flux, and therefore, the air will become unstable, which will change the aerodynamic resistance. This will provide the input for the next iteration step. This iteration is performed multiple times to find the final sensible heat flux.

Evaporative Fraction (EF): The instantaneous EF is calculated using the following equation:

$E_{\text {inst }}=\frac{\lambda E}{\lambda E+H}$

The instantaneous evaporative fraction can be used to calculate the daily ET. The daily evaporation is calculated using the following equation:

$\mathrm{ET}_{24}=\mathrm{EF}_{\text {inst }} \times \mathrm{AF} \times \frac{\mathrm{R}_{\mathrm{n} 24}}{\lambda \times \rho_{\mathrm{w}}} \times 86400000$

where $\mathrm{AF}$ is the advection factor, $\lambda$ is the latent heat of vaporization $\left(\mathrm{J} \mathrm{kg}^{-1}\right)$ and $\rho w$ is the density of water $\left(\mathrm{kg} . \mathrm{m}^{-}\right.$ ${ }^{3}$ ). The advection factor is used to account for any effects 
of regional advection and is calculated by the following equation:

$\mathrm{AF}=1+0.985\left(\exp \left(\left(\mathrm{e}_{\mathrm{sat} \_24}-\mathrm{e}_{\mathrm{act} \_24}\right) \times 0.08\right)-\right.$

1) $\mathrm{EF}_{\text {inst }}$

where $e_{s a t} 24$ is the 24-hour averaged saturated vapor pressure $(\mathrm{kPa})$ and $e_{a c t} 24$ is the 24-hour averaged actual vapor pressure $(\mathrm{kPa})$.

\subsection{Statistical Analysis}

Statistical comparison between actual evapotranspiration obtained by the pySEBAL model and by the lysimeter method was done using a simple linear regression. Others statistical evaluations, such as the root mean square error (RMSE), the coefficient of determination $\left(\mathrm{R}^{2}\right)$, the Willmott's index of agreement $(d)$ and the mean bias error (MBE) were used to determine the relationships between $\mathrm{ET}_{\mathrm{a}}$ obtained from the pySEBAL model and from the lysimeter method.

\section{RESULTS AND DISCUSSIONS}

\subsection{PySEBAL Model Based ET $\mathrm{T}_{\mathrm{a}}$ Maps}

Fig. 1 and Fig. 2 shows maps of daily actual evapotranspiration around the area of interest. The white small square in Fig. 1 and Fig. 2 shows the pixel selected for $\mathrm{ET}_{\mathrm{a}}$ data collection. The selected pixel shows the lysimeter field. The Day of Year (DOY) 197 and the DOY 245 of the Fig. 1 and Fig. 2, respectively, shows the variation of ET $\mathrm{E}_{\mathrm{a}}$ by the pySEBAL model throughout the 2009 growing season. The $\mathrm{ET}_{\mathrm{a}}$ was $2.3 \mathrm{~mm}^{\mathrm{day}}{ }^{-1}$ and 3.1 mm.day $^{-1}$ for the DOY 197 and the DOY 245, respectively. The increased values of $\mathrm{ET}_{\mathrm{a}}$ from the DOY 197 to the DOY 245 are attributed to the crop growth and meteorological conditions.

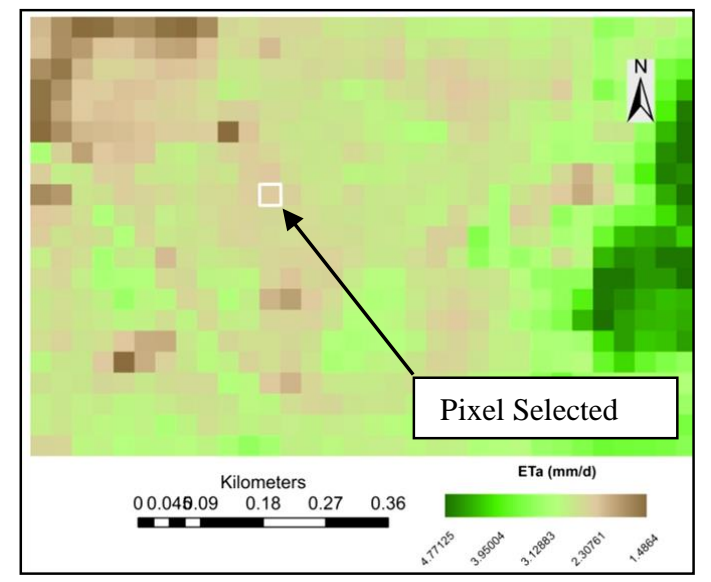

Fig.1. ETa map of the DOY 197

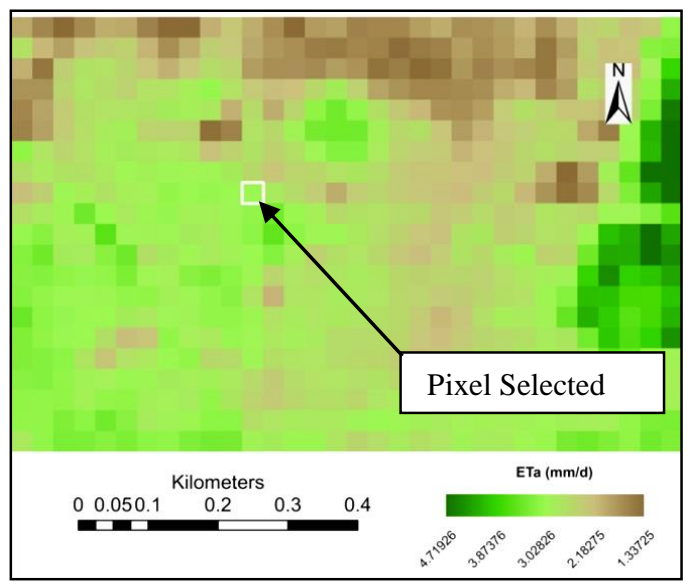

Fig.2. ETa map of the DOY 245

\subsection{Comparison of ET $_{\mathrm{a}}$ by the PySEBAL Model

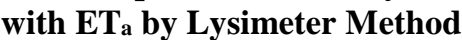

A simple linear relationship between $\mathrm{ET}_{\mathrm{a}}$ from the pySEBAL and $\mathrm{ET}_{\mathrm{a}}$ from the lysimeter method is shown in Fig. 3. The Statistical comparison between $\mathrm{ET}_{\mathrm{a}}$ from the pySEBAL model and $\mathrm{ET}_{\mathrm{a}}$ from the lysimeter method is shown in Table 4. The results revealed that the RMSE was $0.51 \mathrm{~mm} . \mathrm{day}^{-1}$, the $\mathrm{R}^{2}$ was 0.73 , the MBE was 0.04 and, the $d$ was 0.9 . The results of the simple linear regression showed a good relationship between $\mathrm{ET}_{\mathrm{a}}$ by the pySEBAL model and $\mathrm{ET}_{\mathrm{a}}$ by the lysimeter method and have been confirmed by many researchers. Similar results in $\mathrm{R}^{2}$ (0.76) was reported by Ruhoff et al. (2012) by comparing $\mathrm{ET}_{\mathrm{a}}$ estimated by the SEBAL model with $\mathrm{ET}_{\mathrm{a}}$ measured by the eddy-covariance method for sugarcane croplands. Zamansani et al. (2018) also found a good coefficient of determination of 0.77 by comparing actual ET from the SEBAL model with actual ET from the lysimeter method for wheat crops. Based on the $\mathrm{R}^{2}$ in this study, $\mathrm{ET}_{\mathrm{a}}$ by the pySEBAL model and $\mathrm{ET}_{\mathrm{a}}$ by the lysimeter method showed a good accuracy between the two data sets. For the RMSE found in this study, Bala et al. (2015) reported similar results in RMSE of $0.51 \mathrm{~mm} \cdot \mathrm{d}^{-1}$ by comparing $\mathrm{ET}_{\mathrm{a}}$ estimated by the SEBAL model and $\mathrm{ET}_{\mathrm{a}}$ measured by the lysimeter method. In addition, Hassanpour et al. (2011) by comparing $\mathrm{ET}_{\mathrm{a}}$ estimated by the SEBAL model and $\mathrm{ET}_{\mathrm{a}}$ measured by the lysimeter method found an RMSE of 0.29 mm.day ${ }^{-1}$. Bhattarai et al. (2011) by comparing $\mathrm{ET}_{\mathrm{a}}$ estimated by the SEBAL model and $\mathrm{ET}_{\mathrm{a}}$ measured by the eddy covariance method on grass crop, reported a MBE of $0.05 \mathrm{~mm}^{-1 a y}{ }^{-1}$, and then confirm the MBE of 0.04 mm.day ${ }^{-1}$ found in this study. The Willmott's index of agreement of 0.9 and the lower values of RMSE and MBE indicates better performance of the pySEBAL model to estimate the $\mathrm{ET}_{\mathrm{a}}$. 


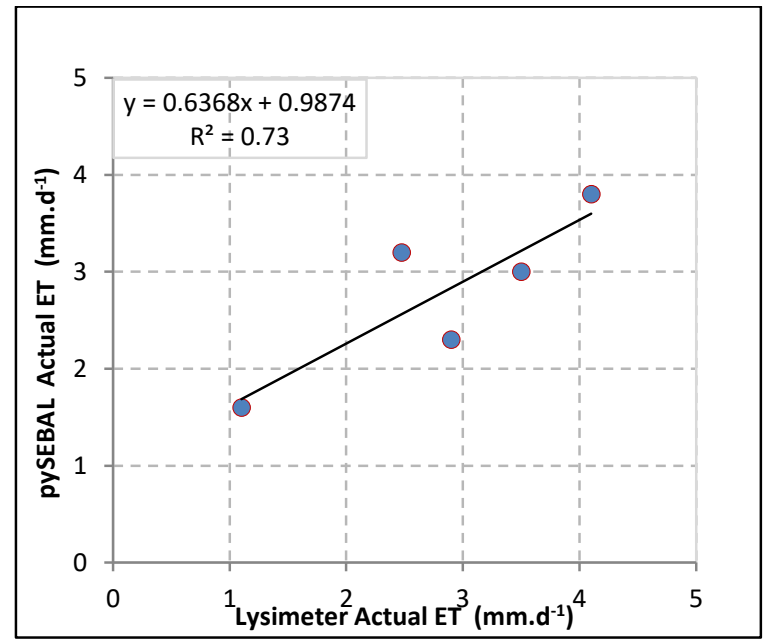

Fig. 3. The relationship between ETa from lysimeter and ETafrom pySEBAL.

Table.4. Statistic results of $\mathrm{ET}_{\mathrm{a}}$ from pySEBAL and $\mathrm{ET}_{\mathrm{a}}$ from lysimeter

\begin{tabular}{|c|c|}
\hline Statistic parameters & Actual evapotranspiration \\
\hline RMSE $\left(\mathrm{mm}^{2}\right.$ day $\left.^{-1}\right)$ & 0.51 \\
\hline $\operatorname{MBE}\left(\mathrm{mm} \cdot \mathrm{day}^{-1}\right)$ & 0.04 \\
\hline $\mathrm{R}^{2}$ & 0.73 \\
\hline$d$ & 0.90 \\
\hline
\end{tabular}

RMSE $=$ Root Mean Square Error

$\mathrm{MBE}=$ Mean Bias Error

$\mathrm{R}^{2} \quad=$ Coefficient of determination

$d \quad=$ Willmott index of agreement

The capability of the SEBAL model to estimate actual ET with $\mathrm{R}^{2}$ close to one is shown by many researchers. Bala et al. (2015) found an $\mathrm{R}^{2}$ of 0.91 by comparing $\mathrm{ET}_{\mathrm{a}}$ estimated by the SEBAL model and $\mathrm{ET}_{\mathrm{a}}$ measured by the lysimeter method. The estimation of $\mathrm{ET}_{\mathrm{a}}$ by the SEBAL model as a residual energy of energy balance equation should therefore be as accurate as possible in $R_{n}, H$ and $G$ estimation. Therefore, the accuracy of SEBAL model can be affected by many errors related in $R_{n}, H$ and $G$ estimation. Bastiaanseen et al. (2005) shown that the typical accuracy of SEBAL is $85 \%$ at field scale on a daily basis. One of the important source of error at field scale in $\mathrm{ET}_{\mathrm{a}}$ estimation by the SEBAL model is the advection effect. Mkhwanazi and Chávez (2013) by comparing the SEBAL model under advective and non-advective conditions found and error ranged between 5 and $46 \%$. Singh et al. (2008) observed an error of $28 \%$ for the SEBAL model due to advection effect. At regional scale, pySEBAL model include an advection factor to account for any effects of regional advection (Eq. [7]). Unfortunately, the minimum scale at which advection will have to be considered remain a research challenge. In this study, the small experimental area of 0.12 ha could be prone to decrease the accuracy of the pySEBAL model due to advection effect. The validation of remote sensing data with ground truth observation is the dissimilarity between the spatial scales of field and satellite data (Orhan et al.,
2019). With an $R^{2}$ of 0.73 , an RMSE of $0.51 \mathrm{~mm}^{-d a y}{ }^{-1}$, an

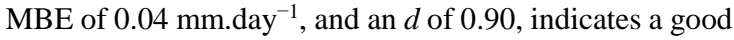
accuracy of the pySEBAL model in daily $\mathrm{ET}_{\mathrm{a}}$ estimation of soybean crop in Adana, Turkey.

\section{CONCLUSION}

We have evaluated the pySEBAL model in Adana, Turkey by comparing $\mathrm{ET}_{\mathrm{a}}$ estimated by the pySEBAL model with $\mathrm{ET}_{\mathrm{a}}$ measued by lysimeter method. In this study, Landsat 5 Thematic Mapper images were used to estimate the ET $\mathrm{a}_{\mathrm{a}}$ by pySEBAL model. The results showed a good relationship between $\mathrm{ET}_{\mathrm{a}}$ estimated by the pySEBAL model and $\mathrm{ET}_{\mathrm{a}}$ measured by the lysimeter

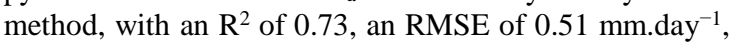
an MBE of 0.04 mm.day ${ }^{-1}$ and a Willmott's index of agreement $(d)$ of 0.90 . Based on the results of this study, $\mathrm{ET}_{\mathrm{a}}$ of soybean crops can be estimated with high accuracy by pySEBAL model in Adana, Turkey. Success of pySEBAL model $\mathrm{ET}_{\mathrm{a}}$ estimation depends on the availability of Landsat cloud-free images. In this study, the availability of Landsat cloud-free images was limited. Thus, the application of pySEBAL model with more satellite images is recommended.

\section{ACKNOWLEDGMENT}

This study was possible thanks to the support of the Presidency for Turks Abroad and Related Communities (YTB).

\section{REFERENCES}

Allen, R. G., Pereira, L.S., Raes, D., and Smith, M. 1998. "Crop evapotranspiration: Guidelines for computing crop water requirements." FAO irrigation and drainage paper 56, Food and Agriculture Organization of the United Nations, Rome. p. 1-209.

Allen, R. G., Tasumi, M., and Trezza, R. 2007. Satellitebased energy balance for mapping evapotranspiration with internalized calibration (METRIC)-Model. Journal of Irrigation and Drainage Engineering, 133, 380-394.

Anonymous. 2007. Water for Food, Water for Life: A Comprehensive Assessment of Water Management in Agriculture. London: Earthscan, and Colombo: International Water Management Institute.

Bala, A., Rawat, K. S., Misra, A. K., and Srivastava, A. 2015. Assessment and validation of evapotranspiration using SEBAL algorithm and Lysimeter data of IARI agricultural farm, India. GEOCARTO INT. DOI: 10.1080/10106049.2015.1076062.

Bastiaanssen, W. G. M. 1995. Regionalization of surface flux densities and moisture indicators in composite terrain: a remote sensing approach under clear skies in Mediterranean climates. Ph.D. dissertation, CIP Data Koninklijke Bibliotheek, Den Haag, The Netherlands. 273 pp.

Bastiaanssen, W. G. M., Menenti, M., Feddes, R. A., and Holtslag, A. A. M. 1998. A remote sensing surface energy 
balance algorithm for land (SEBAL) . 1. Formulation. J HYDROL. 212(1-4), 198-212.

Bastiaanssen, W. G. M., Noordman, E. J. M., Pelgrum, H., Davids, G., Thoreson, B. P., and Allen, R. G.2005. SEBAL model with remotely sensed data to improve waterresources management under actual field conditions. J IRRIG DRAIN ENG. 131, 85-93.

Bhattarai, N., Dougherty, M., Marzen, J. L., and Kalin, L. 2011. Validation of evaporation estimates from a modified surface energy balance algorithm for land (SEBAL) model in the south-eastern United States. REMOTE SENS LETT. 3: 6, 511-519.

Centinari, M., Poni, S., Filippetti, I., Magnanini, E., and Intrieri, C. 2009. Evaluation of an open portable chamber system for measuring cover crop water use in a vineyard and comparison with a mini-lysimeter approach. AGR FOREST METEOROL. 149: 11, 1975-1982.

Ernst , F., Erdoğan, S., Bayram, Y. 2019. Human resource management using geographic information systems (gis): an example from Turkish land registry directorates. International Journal of Engineering and Geosciences (IJEG), Vol; 2; Issue; 02, pp. 41-51.

FAO. 2009. How to feed the world in 2050. Issue brief from the High-Level Expert Forum held in Rome, 12-13 October. FAO, Rome, Italy.

FAO. 2011. The state of the world's land and water resources for food and agriculture (SOLAW)-managing systems at risk. Food and Agriculture Organization of the United Nations, Rome and Earthscan, London.

Hassanpour, B., Mirzaie, F., Arshad, S., and Bakhtiari, B. 2011: Comparison of SEBAL based evapotranspiration with lysimeter data. ICID J. 21st International Congress on Irrigation and Drainage.

Iscan, F., Ilgaz, A., 2017. Analysis of Geographic/Urban Information System Web Presentations of Local Goverments In Turkey, International Journal of Engineering and Geosciences (IJEG), Vol; 2; Issue; 03, pp. 75-83.

Mata, M., Girona, J., Goldhammer, D., Fereres, E., Cohen, M., and Johnson, S. 1999. Water relations of lysimetergrown peach trees are sensitive to deficit irrigation. CALIF AGR. 17-21.

Mkhwanazi, M. M., and Chávez, J. L. 2013. Mapping evapotranspiration with the remote sensing ET algorithms METRIC and SEBAL under advective and non-advective conditions: accuracy determination with weighing lysimeters. Hydrology Days. Colorado State University.

Orhan, O., Dadaser-Celik, F., Ekercin, S. 2019. Investigating Land Surface Temperature Changes Using Landsat-5 Data And Real-Time Infrared Thermometer Measurements At Konya Closed Basin In Turkey, International Journal of Engineering and Geosciences (IJEG), Vol; 4, Issue; 1, pp. 016-027.
Roerink, G.J., Su, Z., Menenti, M. 2000. S-SEBI: A simple remote sensing algorithm to estimate the surface energy balance. Phys. Chem. Earth, Part B Hydrol. Oceans Atmos. 25 (2), 147-157. https://doi.org/10.1016/S14641909(99)00128-8.

Ruhoff, A., Paz, A. R., Collischonn, W., Aragao, L. E. O. C., Rocha, H. R., Yadvinder, S., and Malhi, Y. S. 2012. A MODIS-Based Energy Balance to Estimate Evapotranspiration for Clear-Sky Days in Brazilian Tropical Savannas. REMOTE SENS-BASEL. 4(3) 703725. doi:10.3390/rs4030703.

Singh, R. K., Irmak, A., Irmak, S., and Martin, D. L. 2008: Application of SEBAL Model for mapping evapotranspiration and estimating surface energy fluxes in South-Central Nebraska. J IRRIG DRAIN E-ASCE. 134 (3): $273-285$.

Su, Z., 2002. The Surface Energy Balance System (SEBS) for estimation of turbulent heat fluxes. Hydrol. Earth Syst. Sci. 6, 85-99.

Uncu, H. A., and Arioglu, H.2005. Ikinci urun soya tariminda farklı ekim zamanlarina gore bazi buyume duzenleyicilerin verim ve kalite uzerine etkileri, Turkiye VI. Tarla Bitkileri Kongresi, 5-9 Eylul, Antalya, 1: 375380 .

Zamansani, E., Khoorani, A., Sadeghi-e-lari, A., and Sadidi, J. 2018. Evaluation of evapotranspiration of wheat using SEBAL algorithm (Case study: Agricultural Research Station of Haji Abad). University of Tehran. 